\title{
Silver(I) and copper(II)-imidazolium carboxylates: Efficient catalysts in Ullmann coupling reactions
}

\author{
GANESAN PRABUSANKAR $^{\mathrm{a}, *}$, CHATLA NAGA BABU ${ }^{\mathrm{a}}$, GEMBALI RAJU ${ }^{\mathrm{a}}$ \\ and NATARAJAN SAMPATH ${ }^{\mathrm{b}}$ \\ a Department of Chemistry, Indian Institute of Technology Hyderabad, Kandi, Sangareddy, \\ Telangana 502 285, India \\ ${ }^{\mathrm{b}}$ School of Chemical and Biotechnology, SASTRA University, Tirumalaisamudram, Thanjavur, \\ Tamil Nadu 613 401, India \\ Email: prabu@iith.ac.in
}

MS received 2 December 2016; revised 7 March 2017; accepted 9 March 2017

\begin{abstract}
The silver(I) and copper(II)-imidazolium carboxylate coordination assemblies were derived from the reaction between corresponding carboxylic acid ligands and metal salts. These new metal derivatives depict a novel structural motif with variable chemical and thermal properties. These metal complexes act as potential catalysts in Ullmann coupling reactions. The imidazolium linker present in these complexes plays a role as both ligand and counter ion to balance the metal charge.
\end{abstract}

Keywords. Copper(II); Silver(I); Coordination polymer; Imidazolium ion; Ullmann coupling.

\section{Introduction}

Carboxylate-functionalized imidazolium organic spacers are known as the most promising chelating ligands in proton conduction, ${ }^{1}$ gas storage, ${ }^{2,3}$ and catalysis ${ }^{2,4-8}$ applications. For example, the well defined heterogeneous catalysts were derived from pre- or post-modified metal imidazolium derivatives. ${ }^{2,4-8}$ However, the synthetic approach for pre- or post-modified metal imidazolium derivatives are most challenging and very few examples have been demonstrated (Chart 1).

The first catalytic application of copper-palladiumimdizolium carboxylate for Suzuki-Miyaura cross-coupling reaction was demonstrated through post-modified route. ${ }^{4}$ Later, zinc-palladium-imdizolium carboxylate was reported through post-modified route for Suzuki-Miyaura coupling reaction, Heck coupling reaction, hydrogenation of olefins and reduction of nitrobenzene. ${ }^{4}$ The postmodified cobalt-imdizolium carboxylate-mediated synthesis of methyl ether from $\alpha, \beta$-unsaturated ketone was reported. ${ }^{7}$ The first pre-modified zinc-copperimdizolium carboxylate was reported for hydroboration of carbondioxide. ${ }^{6}$ Recently, we demonstrated the highly active lead(II)-imidazolium coordination assemblies for benzoin condensation reactions. ${ }^{8}$ In this paper, we report the first example of Ullmann reactions

*For correspondence mediated by silver(I) and copper(II)-imidazolium coordination polymers. These newly prepared catalysts are highly active towards Ullmann reaction.

\section{Experimental}

\subsection{Materials and methods}

The solvents were purchased from commercial sources and purified according to the standard procedures and freshly distilled under argon atmosphere prior to use. ${ }^{9}$ Unless otherwise stated, all the chemicals were purchased from commercial sources. 2-(1-(carboxymethyl)-1 $H$-imidazol-3-ium-3-yl)acetate $\left(\mathbf{L}^{1} \mathbf{H}\right)$ and 2-(1-(1-carboxyethyl)-1 $H$-imidazol-3-ium-3-yl) propanoate $\left(\mathbf{L}^{2} \mathbf{H}\right)$ were prepared as previously reported. ${ }^{10}$ FTIR measurement (neat) was carried out on a Bruker Alpha-P Fourier transform spectrometer. The UV-Vis spectra were measured on a T90+ UV-Visible spectrophotometer. Thermogravimetric analysis (TGA) was performed using a TASDT Q600, Tzero-press. NMR spectra were recorded on Bruker Ultrashield- 400 spectrometers at $25^{\circ} \mathrm{C}$ unless otherwise stated. Chemical shifts are given relative to TMS and were referenced to the solvent resonances as internal standards. The crystal structures of $\mathbf{1}$ and $\mathbf{2}$ were measured on an Oxford Xcalibur 2 diffractometer. Single crystals of complexes suitable for the single crystal X-ray analysis were obtained from their reaction mixture at room temperature and the suitable single crystals for X-ray structural analysis were mounted at $150 \mathrm{~K}$ for $\mathbf{1}$ and $298 \mathrm{~K}$ for $\mathbf{2}$ in inert oil. Using Olex $2,{ }^{11}$ the structure was solved with 


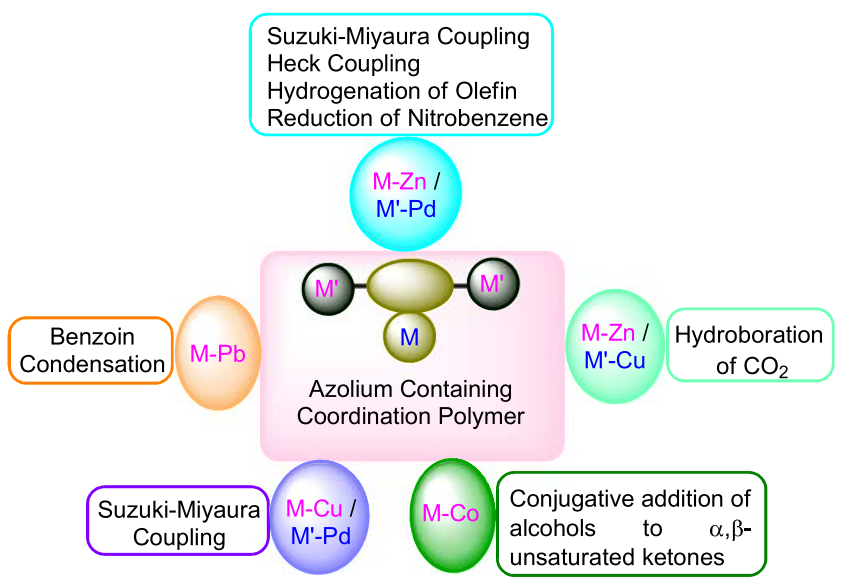

Chart 1. Known catalytic reactions with azoliumcontaining coordination polymers.

the ShelXS structure solution program using Direct Methods and refined with the olex2.refine refinement package using Gauss-Newton minimization. Absorption corrections were performed on the basis of multi-scans. Data quality of 2 was not very good. Molecule $\mathbf{2}$ depicted "B" level alerts. Attempts to get better quality data were not successful. This may be due to the copper X-ray source as well as the chiral centre present in the ligands as reported for similar work. ${ }^{10 \mathrm{c}}$ Non-hydrogen atoms were anisotropically refined. Hydrogen atoms were included in the refinement in calculated positions riding on their carrier atoms. No restraint has been made for any of the compounds. ${ }^{1} \mathrm{H}$ NMR, ${ }^{13} \mathrm{C}$ NMR and FT-IR data for $\mathbf{1}$ and $\mathbf{2}$ are shown in Figures S1-S6 (in Supplementary Information).

\subsection{Synthesis of $\mathbf{1}$}

To a mixture of $\mathrm{AgNO}_{3}(0.543 \mathrm{mmol}, 0.092 \mathrm{~g})$ and $\mathbf{L}^{1} \mathbf{H}$ $(0.271 \mathrm{mmol}, 0.050 \mathrm{~g})$, methanol $(2 \mathrm{~mL})$ and water $(1$ $\mathrm{mL}$ ) was added, under stirring condition, until the reaction mixture became clear. The reaction mixture was maintained at room temperature for two days. Colourless crystals of 1 were obtained within $12 \mathrm{~h}$. Yield: 52\% (Based on $\mathrm{AgNO}_{3}$ ). M.p.: $212-214^{\circ} \mathrm{C}$ (decomposed to black solid). FTIR (Neat, $\bar{U} / \mathrm{cm}^{-1}$ ): 3341(b), 3113(m), 3071(m), 2999(m), 2960(m), 2326(w), 1734(m), 1567(s), 1329(s), 1289(vs), 1169(s), 1031(m), 965(m), 908(w), 862(m), 776(m), 691(s), 629(w), 576(w). ${ }^{1} \mathrm{H}$ NMR (DMSO- $d_{6}, 400.13 \mathrm{MHz}$ ): $\delta 9.08$ $(\mathrm{s}, 1 \mathrm{H}, \operatorname{Im} H), 7.68(\mathrm{~d}, 2 \mathrm{H}, \operatorname{Im} H), 5.06\left(\mathrm{~s}, 4 \mathrm{H}, \mathrm{CH}_{2}\right) \mathrm{ppm} .{ }^{13} \mathrm{C}$ NMR (DMSO- $\left.d_{6}, 100.613 \mathrm{MHz}\right): \delta 168.16(C=\mathrm{O}), 137.92$ $(\operatorname{Im} C), 123.21(\operatorname{Im} C), 50.32\left(C \mathrm{H}_{2}\right)$ ppm.

\subsection{Synthesis of 2}

To a mixture of $\mathrm{Cu}\left(\mathrm{NO}_{3}\right)_{2} \cdot 6 \mathrm{H}_{2} \mathrm{O}(0.471 \mathrm{mmol}, 0.113 \mathrm{~g})$, $\mathbf{L}^{2} \mathbf{H}(0.235 \mathrm{mmol}, 0.050 \mathrm{~g})$ and $\mathrm{HCOOH}(0.235 \mathrm{mmol}, 0.011$ $\mathrm{g})$, DMF ( $2 \mathrm{~mL})$ and water $(1 \mathrm{~mL})$ was added; then, the suspension was heated at $80^{\circ} \mathrm{C}$. The reaction mixture became clear pale blue solution after $30 \mathrm{~min}$ and then the reaction condition was maintained at the same temperature for $12 \mathrm{~h}$. The reaction mixture was slowly brought to room temperature to yield single crystals of 2 within $24 \mathrm{~h}$. Yield: $48 \%$ (Based on $\mathrm{Cu}\left(\mathrm{NO}_{3}\right)_{2} \cdot 6 \mathrm{H}_{2} \mathrm{O}$ ). M.p.: $218-220^{\circ} \mathrm{C}$. FT-IR (Neat, $\left.\bar{U} / \mathrm{cm}^{-1}\right)$ : 3419(b), 3149(m), 3081(m), 2933(m), 1663(vs), 1575(m), 1498(w), 1464(w), 1384(s), 1255(m), 1182(m), 1085(vs), 882(m), 791(w), 761(w), 737(w), 709(w), 661(s), 619(m). ${ }^{1} \mathrm{H}$ NMR $\left(\mathrm{D}_{2} \mathrm{O}, 400.13 \mathrm{MHz}\right): \delta 8.32$ (bs, $\left.1 \mathrm{H}, \operatorname{Im} H\right)$, 7.30 (bs, 2H, ImH), 2.92 (bs, 1H, CH), 2.76 (b, 2H, CH), 2.19 (bs, $\left.3 \mathrm{H}, \mathrm{CH}_{3}\right)$ ppm. ${ }^{13} \mathrm{C}$ NMR $\left(\mathrm{D}_{2} \mathrm{O}, 100.613 \mathrm{MHz}\right): \delta$ $165.67(C=\mathrm{O}), 137.12(\operatorname{Im} C), 121.95(\operatorname{Im} C), 37.08,34.48$, $31.50(\mathrm{CH}), 16.06\left(\mathrm{CH}_{3}\right) \mathrm{ppm}$.

\subsection{Ullmann reaction}

Oven-dried Schlenk was charged with catalyst (1 mol\%) and iodobenzene and dried under vacuum for $5 \mathrm{~min}$. Solvent $(5 \mathrm{~mL})$ was added under inert condition to the reaction mixture, evacuated for few seconds, refilled with nitrogen and then $\mathrm{KOH}(5 \mathrm{~mol} \%)$ was added to the reaction mixture under nitrogen condition at room temperature. The progress of the reaction was monitored by TLC. The reaction mixture was diluted with water $(10 \mathrm{~mL})$ and DCM $(10 \mathrm{~mL})$. The organic phase was separated, washed with brine solution $(7 \mathrm{~mL})$, dried over anhydrous sodium sulphate and then the reaction mass was concentrated under reduced pressure to get
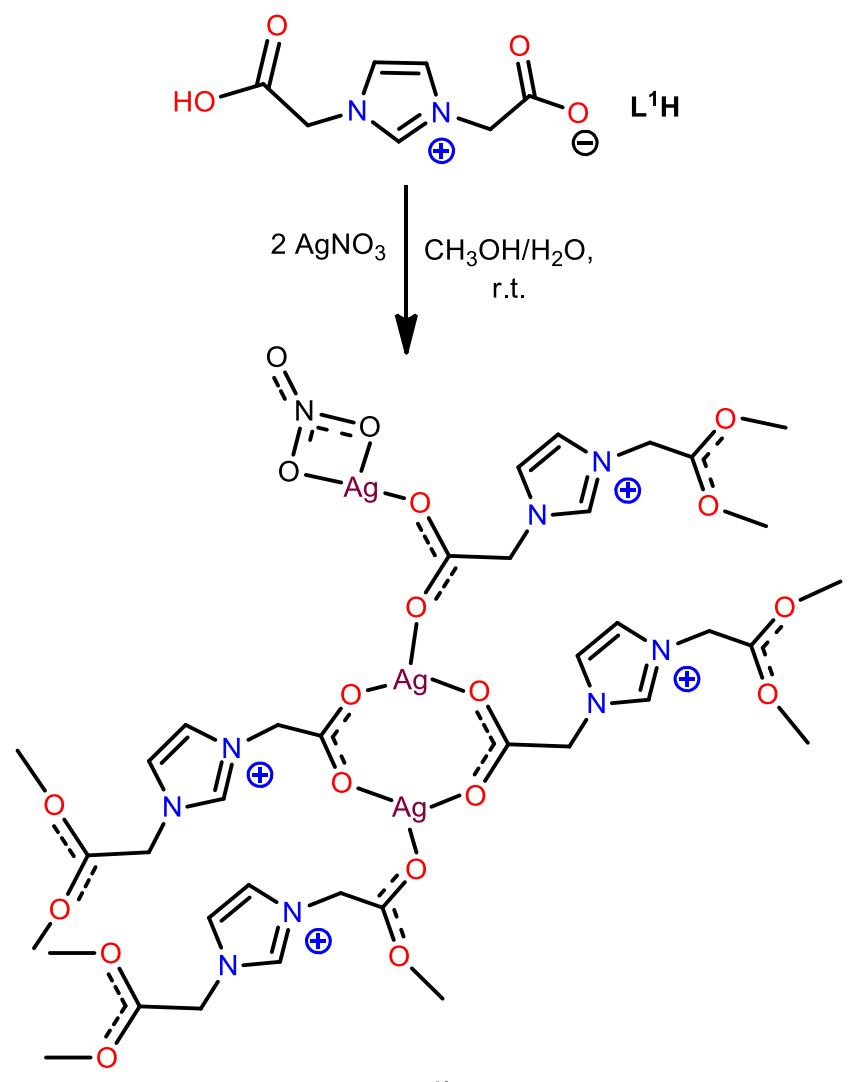

(1)

Scheme 1. Synthesis of 1. 
the crude compound. The crude compound was adsorbed on silica gel (100-200 mesh) for purification; then, petroleum ether and $10 \%$ ethyl acetate/petroleum ether $(200 \mathrm{~mL})$ were poured on the column to separate the final product.

\section{Results and Discussion}

The zwitterionic salt of $\mathbf{1}$ was isolated from the reaction between 2-(1-(carboxymethyl)-1 $H$-imidazol-3-ium-3yl)acetate $\left(\mathbf{L}^{1} \mathbf{H}\right)$ and $\mathrm{AgNO}_{3}$ (Scheme 1). The FT-IR spectrum of $\mathbf{1}$ showed the characteristic frequency at 1734 and $1567 \mathrm{~cm}^{-1}$ for the presence of mono and bidentate mode of carboxylate groups. The bidentate mode of coordinating $\mathrm{NO}_{3}^{-}$ion appears at 1329 and $1289 \mathrm{~cm}^{-1}$. In ${ }^{1} \mathrm{H} \mathrm{NMR}$, the $\mathrm{N}-\mathrm{CH}-\mathrm{N}$ proton appeared at $\delta 9.08 \mathrm{ppm}$. The ${ }^{13} \mathrm{C}$ NMR chemical shift value of $C-\mathrm{O}$ and $\mathrm{N}-\mathrm{CH}-\mathrm{N}$ carbons were detected at $\delta 168.1$ and $137.9 \mathrm{ppm}$, respectively.

The solid state structure of $\mathbf{1}$ was further confirmed by single crystal X-ray diffraction technique (Figure 1). 1 crystallized in the monoclinic space group, $C 2 / c$
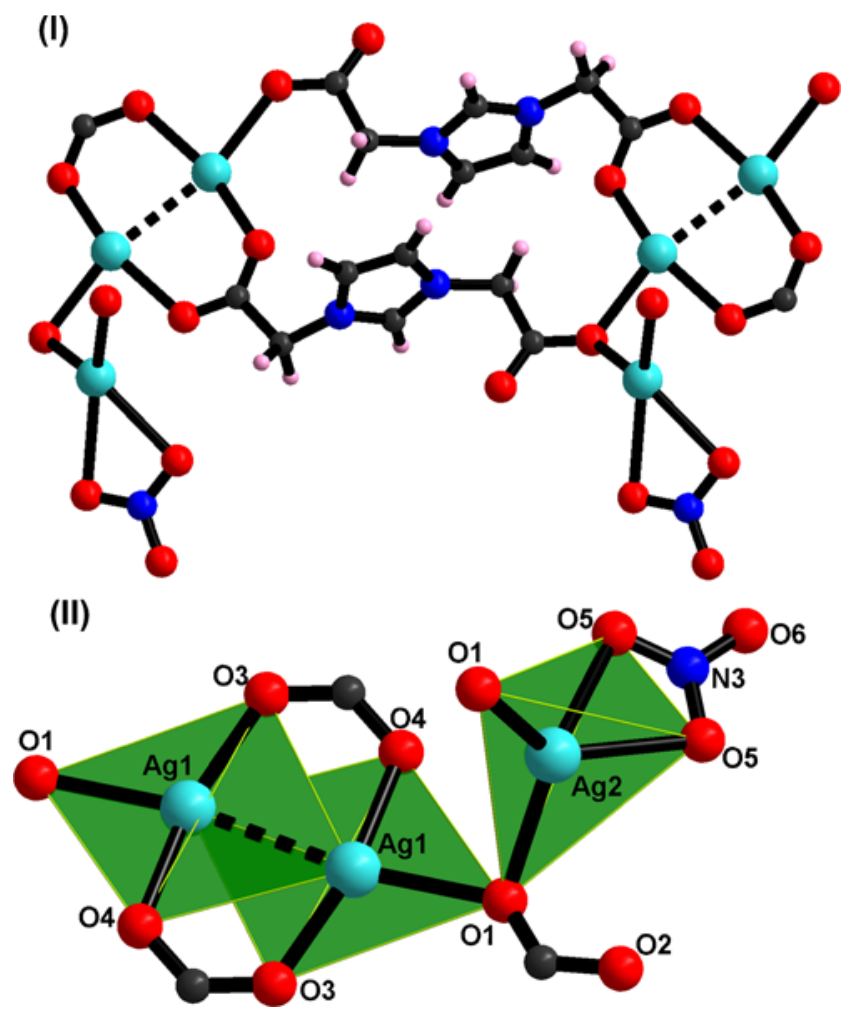

Figure 1. (I) The solid state structure of $\mathbf{1}$. Selected bond lengths $(\AA)$ and angles $\left({ }^{\circ}\right): \operatorname{Ag}(1)-\mathrm{O}(1) 2.370(3), \mathrm{Ag}(1)-$ $\mathrm{O}(4)$ 2.176(3), $\mathrm{Ag}(1)-\mathrm{O}(3)$ 2.212(3), $\mathrm{Ag}(2)-\mathrm{O}(1)$ 2.358(3), $\mathrm{Ag}(2)-\mathrm{O}(5) 2.540(4), \mathrm{Ag}(1)-\mathrm{Ag}(1)$ 2.804(8), O(3)- $\mathrm{Ag}(1)-$ $\mathrm{O}(4) \quad 160.47(12), \quad \mathrm{O}(1)-\mathrm{Ag}(2)-\mathrm{O}(1) \quad 111.39(15), \quad \mathrm{O}(1)-$ $\mathrm{Ag}(2)-\mathrm{O}(5)$ 107.67(12) \& 135.92(13), O(5)-Ag(2)-O(5) 49.93(17); (II) Polyhedron arrangements of silver centre in 1, Hydrogen atoms have been omitted for clarity.
(Table 1). 1 is a first example of zwitterionic, two dimensional silver imidazolium carboxylate coordination polymer constructed by trinuclear silver (Figure 1). ${ }^{10 \mathrm{~b}, \mathrm{c}}$ ] 1 consists of two different types of silver coordinated centres (Figure 1 (I and II)) $\operatorname{Ag}(1)$ and $\operatorname{Ag}(2)$ are tetracoordinated. The geometry and coordination environment of $\operatorname{Ag}(1)$ and $\operatorname{Ag}(2)$ centres in 1 are not comparable. The $\operatorname{Ag}(1)-\operatorname{Ag}(1)$ bond distance is 2.804(8) $\AA$. The geometry of $\mathrm{Ag}(1)$ can be described as distorted square planar and the coordination environment of $\mathrm{Ag}(1)$ is fulfilled by four carboxylate oxygen atoms (Figure 1 (I) and (II)). The square planar silver geometry is considered to be one of the rare coordination geometry for silver(I). $\operatorname{Ag}(2)$ is in distorted tetrahedral geometry by two monodentately coordinated carboxylate oxygen atoms and one nitrate ion. Notably, the trinuclear silver carboxylate coordination polymer with different geometrical arrangement is very rare. $^{12}$ The $\mathrm{Ag}(1)-\mathrm{O}(4)$ bond distance $(2.176(3) \AA)$ is much shorter than that of $\mathrm{Ag}(2)-\mathrm{O}(5)(2.540(4) \AA)$. The $\mathrm{O}-\mathrm{Ag}-\mathrm{O}$ angle varies from $49.93(17)^{\circ}(\mathrm{O}(5)-\mathrm{Ag}(2)-$ $\mathrm{O}(5))$ to $160.47(12)^{\circ}(\mathrm{O}(3)-\mathrm{Ag}(1)-\mathrm{O}(4))$.

The cationic salt 2 was obtained from the reaction between 2-(1-(1-carboxyethyl)-1 $\mathrm{H}$-imidazol-3-ium-3yl)propanoate $\left(\mathbf{L}^{2} \mathbf{H}\right)$ and $\mathrm{Cu}\left(\mathrm{NO}_{3}\right)_{2} \cdot 6 \mathrm{H}_{2} \mathrm{O}$ (Scheme 2). The FT-IR spectrum of $\mathbf{2}$ shows the characteristic frequency at 1663 and $1575 \mathrm{~cm}^{-1}$ for the presence of bridging bidentate mode of coordinated carboxylate

Table 1. Structural parameters of $\mathbf{1}$ and $\mathbf{2}$.

\begin{tabular}{|c|c|c|}
\hline Parameters & 1 & 2 \\
\hline Empirical formula & $\mathrm{C}_{14} \mathrm{H}_{14} \mathrm{Ag}_{3} \mathrm{~N}_{5} \mathrm{O}_{11}$ & $\mathrm{C}_{19} \mathrm{H}_{22} \mathrm{Cu}_{2} \mathrm{~N}_{4} \mathrm{O}_{10}$ \\
\hline Formula weight & 751.91 & 593.48 \\
\hline Temperature & 150 & 293 \\
\hline Crystal system & Monoclinic & Orthorhombic \\
\hline Space group & $\mathrm{C} 2 / \mathrm{c}$ & Pnma \\
\hline $\mathrm{a} / \AA$ & $21.6587(16)$ & $16.0227(6)$ \\
\hline $\mathrm{b} / \AA$ & $8.3304(3)$ & $12.2031(5)$ \\
\hline $\mathrm{c} / \AA$ & $13.6168(9)$ & $21.2908(7)$ \\
\hline$\alpha /^{\circ}$ & 90.00 & 90 \\
\hline$\beta /{ }^{\circ}$ & $127.000(11)$ & 90 \\
\hline$\gamma /{ }^{\circ}$ & 90.00 & 90 \\
\hline Volume $/ \AA^{3}$ & $1962.1(2)$ & $4162.9(3)$ \\
\hline $\mathrm{Z}$ & 4 & 4 \\
\hline$\rho_{\text {calc }} \mathrm{g} / \mathrm{cm}^{3}$ & 2.545 & 0.947 \\
\hline $\begin{array}{l}\text { Absorption } \\
\text { coefficient } / \mathrm{mm}^{-1}\end{array}$ & 3.039 & 1.575 \\
\hline$F(000)$ & 1448.0 & 1208.0 \\
\hline Reflections collected & 4871 & 11196 \\
\hline Independent reflections & 2261 & 3939 \\
\hline $\mathrm{R}_{\mathrm{int}}$ & 0.0335 & 0.0424 \\
\hline GOF on $F^{2}$ & 1.044 & 1.287 \\
\hline $\mathrm{R}_{1}$ values (all data) & 0.0540 & 0.1195 \\
\hline $\mathrm{wR}_{1}$ values (all data) & 0.0817 & 0.3256 \\
\hline
\end{tabular}


<smiles></smiles>

$\mathbf{L}^{2} \mathbf{H}$

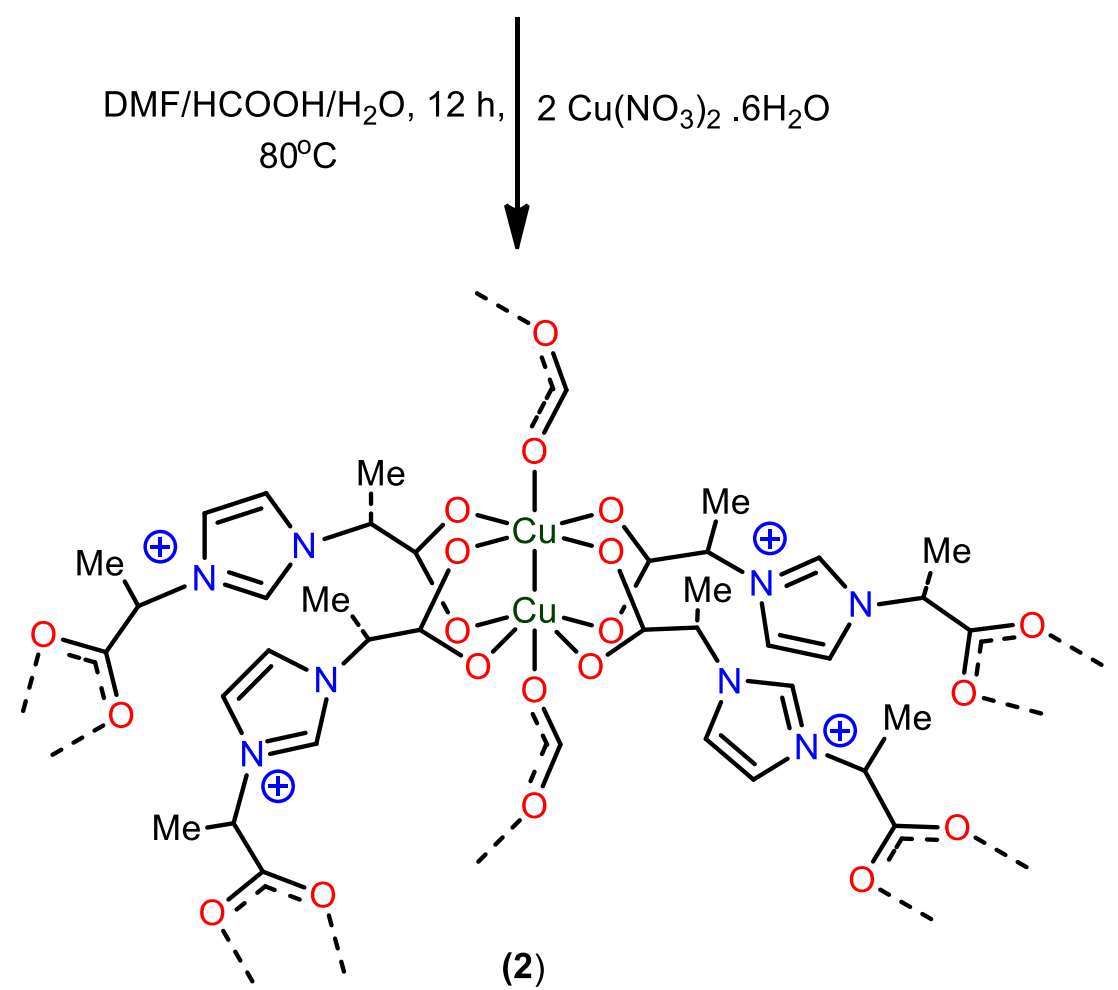

Scheme 2. Synthesis of 2.

group. In ${ }^{1} \mathrm{H} \mathrm{NMR}$, the $\mathrm{N}-\mathrm{CH}-\mathrm{N}$ proton appears at $\delta$ $8.32 \mathrm{ppm}$. In ${ }^{13} \mathrm{C}$ NMR, the chemical shift values for $\mathrm{C}-\mathrm{O}$ and $\mathrm{N}-\mathrm{CH}-\mathrm{N}$ carbons are assigned at $\delta 165.6$ and $137.1 \mathrm{ppm}$, respectively.

The solid state structure of $\mathbf{2}$ was further confirmed by single crystal X-ray diffraction technique (Figure 2). 2 crystallized in the orthorhombic space group, $P_{n m a}$ (Table 1). 2 is a one dimensional cationic coordination polymer. The one dimensional cationic coordination polymer of $\mathbf{2}$ is constructed by copper dimer, which are further bridged by one formate ion and two $\mathbf{L}^{2}$ ligands. The copper dimer is in paddle wheel structure. The charge of each copper(II) dimer is balanced by one formate ion and two $\mathbf{L}^{2}$ ligands. The geometry of copper is satisfied by five carboxylate oxygen atoms, one copper to copper short contact. As shown in Figure 2(II) carboxylates are bidentately bridged between two copper centres. The fifth coordination site is fulfilled by carboxylate moiety in monodentate fashion. The $\mathrm{Cu}-\mathrm{Cu}$ bond distance is $\mathrm{Cu}(1)-\mathrm{Cu}(2)(2.665(14) \AA)$, which is considerably longer than that of $\left[\{(\mathrm{ddp}) \mathrm{GaCu}(\mathrm{OTf})\}_{2}\right](\mathrm{ddp}=2-$ diisopropylphenylamino-4-diisopropylphenylimino-2pentene) (2.277(3) $\AA$ ). ${ }^{13}$ The $\mathrm{Cu}-\mathrm{O}$ bond distances are in the range from 1.965(4) $\AA(\mathrm{Cu}(2)-\mathrm{O}(7))$ to $2.135(5)$ $\AA(\mathrm{Cu}(1)-\mathrm{O}(6))$. The geometry and coordination types of copper centres are comparable. The $\mathrm{O}-\mathrm{Cu}-\mathrm{O}$ angles varies from $86.5(3)^{\circ}(\mathrm{O}(1)-\mathrm{Cu}(1)-\mathrm{O}(1))$ to $167.70(16)^{\circ}$ $(\mathrm{O}(3)-\mathrm{Cu}(2)-\mathrm{O}(2)$.

The solid state and solution state UV-Vis absorption spectra of $\mathbf{1}$ and $\mathbf{2}$ are depicted in Figure S7 (Supplementary Information). The solid state UV-Vis absorption spectra of $\mathbf{1}$ and $\mathbf{2}$ are significantly different from those of solution spectra. In solution, the intense bands in $\mathbf{1}(263 \mathrm{~nm})$ and $\mathbf{2}(270 \mathrm{~nm})$ can be assigned to the $\pi \rightarrow \pi^{*}$ transition, while the absorption band at $427 \mathrm{~nm}$ can be attributed to the $\mathrm{n} \rightarrow \pi^{*}$. In solid state, $\mathbf{1}$ gave a broad band, while 2 gave nearly three broad bands at $247 \mathrm{~nm}\left(\pi \rightarrow \pi^{*}\right), 373 \mathrm{~nm}\left(\mathrm{n} \rightarrow \pi^{*}\right)$, and $767 \mathrm{~nm}$ (LMCT).

The thermal stability of $\mathbf{1}$ and $\mathbf{2}$ was analysed by TGA. Figure S8 (in Supplementary Information) 

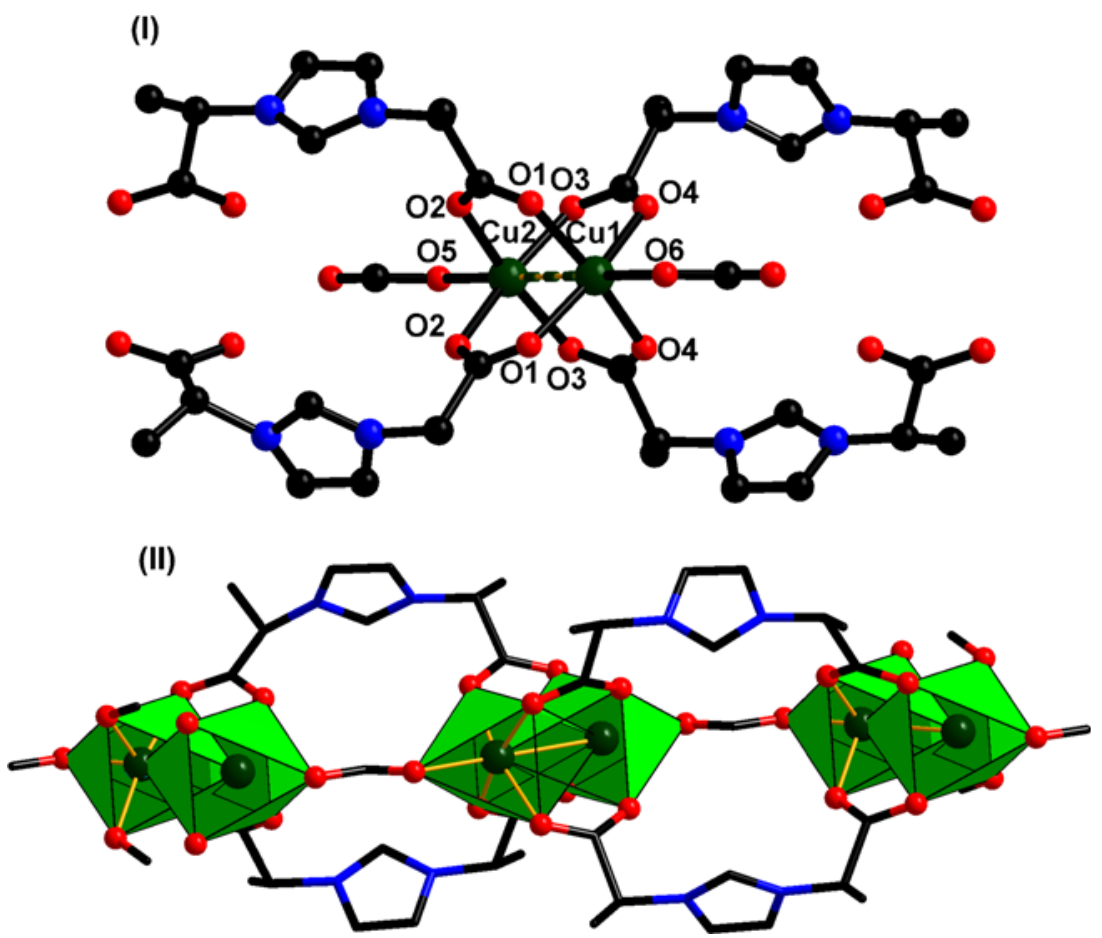

Figure 2. (I) The core structure of $\mathbf{2}$. Hydrogen atoms in $\mathbf{2}$ have been omitted for clarity.Selected bond lengths $(\AA)$ and angles $\left({ }^{\circ}\right)$ : $\mathrm{Cu}(1)-\mathrm{O}(1), 1.994(4)$, $\mathrm{Cu}(1)-\mathrm{O}(4), 1.965(4), \mathrm{Cu}(1)-\mathrm{O}(6), 2.135(4), \mathrm{Cu}(2)-\mathrm{O}(2), 1.974(3), \mathrm{Cu}(2)-$ $\mathrm{O}(3), 1.969(4), \mathrm{Cu}(2)-\mathrm{O}(5), 2.123(5), \mathrm{O}(4)-\mathrm{Cu}(1)-\mathrm{O}(1), 167.63(16), \mathrm{O}(3)-$ $\mathrm{Cu}(2)-\mathrm{O}(2), 167.70(16)$; (II) The polyhedron arrangements of copper centre in 2. Hydrogen atoms in $\mathbf{2}$ have been omitted for clarity.

reveals the thermal breakdown pathway of $\mathbf{1}$ and $\mathbf{2}$ based on thermal investigation under a flowing nitrogen atmosphere $\left(10^{\circ} \mathrm{C} \mathrm{min}^{-1}, 30-1000^{\circ} \mathrm{C}\right)$. A small weight loss $(\sim 2-8 \%)$ was observed for $\mathbf{1}$ and $\mathbf{2}$ in the initial stage $\left(<80^{\circ} \mathrm{C}\right)$, which can be attributed to the loss of moisture. Complexes $\mathbf{1}$ and $\mathbf{2}$ showed the gradual weight loss from 200 to $500^{\circ} \mathrm{C}$, which can be validated as the decomposition of organic moieties. Complex $\mathbf{1}$ shows gradual weight loss till $631^{\circ} \mathrm{C}$, then remains unchanged till $1000^{\circ} \mathrm{C}$. Similarly, complex 2 loses the major weight till $529^{\circ} \mathrm{C}$ and then remains unchanged till $1000^{\circ} \mathrm{C}$.

Furthermore, we attempted to use one mol\% of coordination polymers $\mathbf{1}$ and $\mathbf{2}$ as catalysts for Ullmann reaction in DMF (Scheme 3). The catalytic reactions were analysed with iodobenzene at $130^{\circ} \mathrm{C}$ in the presence of five mol\% potassium hydroxide as base in $\mathbf{1}$ and

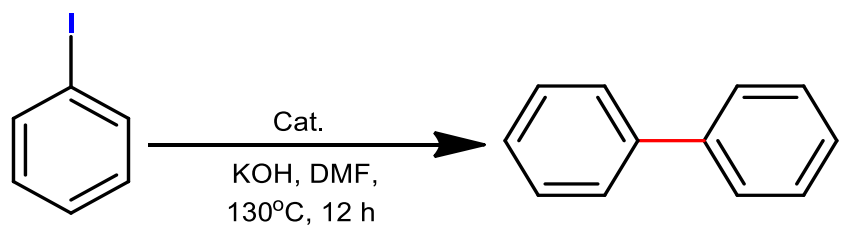

Scheme 3. Ullmann reaction mediated by Catalysts.
2 (Table 2). In contrast to the known methodology, ${ }^{14,15}$ in this work, we used potassium hydroxide salt as deprotonation base to activate silver(I) and copper(II) imidazolium coordination polymers. The catalytic reaction was absent, when the reaction was carried out without catalyst (Table 2, entry 1). Poor Ullmann conversion was obtained when the reaction was carried out using only silver(I) and copper(II) salts (Table 2, entries 2-6). Similarly, the conversion was absent when the

Table 2. Effect of catalyst on the Ullmann reaction.

\begin{tabular}{lcc}
\hline Entry & Catalyst $(1 \mathrm{~mol} \%)$ & Isolated Yield $(\%)^{[\mathrm{a}]}$ \\
\hline 1 & $\mathrm{No}$ & 0 \\
2 & $\mathrm{Cu}\left(\mathrm{NO}_{3}\right)_{2} \cdot 6 \mathrm{H}_{2} \mathrm{O}$ & 25 \\
3 & $\mathrm{AgNO}_{3}$ & 10 \\
4 & $\mathrm{CuCl}_{2}$ & 28 \\
5 & $\mathrm{CuBr}_{2}$ & 31 \\
6 & $\mathrm{Cu}\left(\mathrm{ClO}_{4}\right)_{2} \cdot 6 \mathrm{H}_{2} \mathrm{O}$ & 25 \\
7 & $\mathbf{L}^{1} \mathbf{H}$ & 0 \\
8 & $\mathbf{L}^{2} \mathbf{H}$ & 0 \\
9 & $\mathbf{L}^{\mathbf{1}} \mathbf{H} / \mathrm{AgNO}_{3}$ & 18 \\
10 & $\mathbf{L}^{\mathbf{H}} / \mathrm{Cu}\left(\mathrm{NO}_{3}\right)_{2} \cdot 6 \mathrm{H}_{2} \mathrm{O}$ & 37 \\
11 & $\mathbf{1}$ & 58 \\
12 & $\mathbf{2}$ & 85 \\
\hline
\end{tabular}

[a] Isolated yields by column chromatography. 


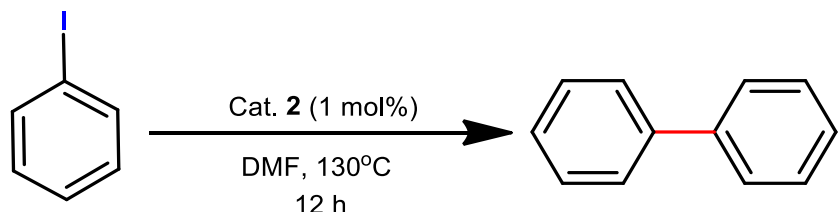

Scheme 4. Effect of base on Ullmann reaction mediated by catalyst 2.

Table 3. Effect of base on catalyst $\mathbf{2}$ in Ullmann reaction.

\begin{tabular}{lcc}
\hline Entry & Base $(5 \mathrm{~mol} \%)$ & Isolated Yield (\%) \\
\hline 1 & $\mathrm{KOH}$ & 85 \\
2 & $\mathrm{~K}_{2} \mathrm{CO}_{3}$ & 67 \\
3 & $\mathrm{Cs}_{2} \mathrm{CO}_{3}$ & 50 \\
4 & $\mathrm{KOAc}$ & 49 \\
5 & $\mathrm{NaOH}$ & 55 \\
\hline
\end{tabular}

[a] Isolated yields by column chromatography.

reactions were studied using only ligands $\left(\mathbf{L}^{1} \mathbf{H}\right.$ and $\mathbf{L}^{2} \mathbf{H}$ ) as organocatalysts (Table 2, entries 7 and 8). As reported in entries 9 and 10 (Table 2), the Ullmann reaction was carried out using one mol\% of in situ silver nitrate and copper nitrate with corresponding imidazolium carboxylate ligands $\left(\mathbf{L}^{1} \mathbf{H}\right.$ and $\left.\mathbf{L}^{2} \mathbf{H}\right)$ in the presence of five mol\% potassium hydroxide. However, the yield of entries 1-10 were not appreciable compared to catalysts 1 and 2 (Table 2, entries 11 and 12). Although, the catalysts $\mathbf{1}$ and $\mathbf{2}$ are very active, $\mathbf{2}$ gave excellent conversion for iodobenzene (Yield, 85\%) (Table 2, entry 12).

In order to understand the choice of base, we investigated the catalytic reaction with different bases in DMF (Scheme 4). KOH (Table 3, entry 1) was found to be more effective than other bases such as $\mathrm{K}_{2} \mathrm{CO}_{3}$, $\mathrm{Cs}_{2} \mathrm{CO}_{3}$, $\mathrm{KOAc}$ and $\mathrm{NaOH}$ (Table 3, entries 2-5). Subsequently, we investigated the scope and the generality of the method under the optimized reaction conditions. Thus, the optimized condition for the Ullmann reaction is reported in Scheme 5. We have investigated the reactions using aryl iodide, aryl bromide and aryl chloride. The results are summarized in Table 4. Catalyst $\mathbf{2}$ is highly active for iodobenzene (Table 4, entry 2), while bromobenzene (Table 4, entry 4) and chlorobenzene (Table 4, entry 6) gave considerable yield.

The catalytic efficiency of $\mathbf{2}$ is comparable with the copper catalyst in Ullmann coupling ${ }^{14}$ However silver(I)-mediated Ullmann reaction is rare. As reported $^{1,5,14}$ silver(I) is expected to mediate the reaction through red-ox mechanism. The catalyst 1mediated Ullmann reaction yield is nearly comparable with copper(II)-mediated reaction. ${ }^{14}$ Although, the mechanism of catalyst $\mathbf{1}$ or $\mathbf{2}$-mediated Ullmann

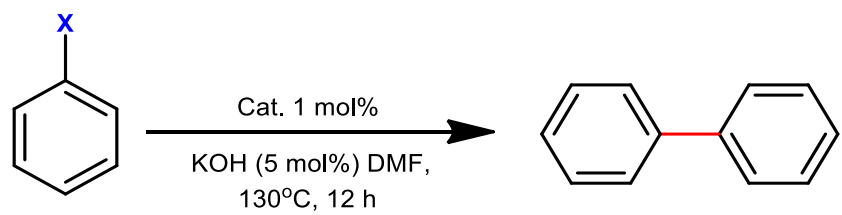

Scheme 5. Evaluation of catalytic scope of $\mathbf{1}$ and $\mathbf{2}$.

Table 4. Evaluation of catalytic scope of $\mathbf{1}$ and $\mathbf{2}$.

\begin{tabular}{llcc}
\hline Entry & Substrate & $\begin{array}{c}\text { Catalyst } \\
(1 \mathrm{~mol} \%)\end{array}$ & $\begin{array}{c}\text { Isolated } \\
\text { Yield (\%) }^{\text {[a] }}\end{array}$ \\
\hline 1 & Iodobenzene & $\mathbf{1}$ & 58 \\
2 & Iodobenzene & $\mathbf{2}$ & 85 \\
3 & Bromobenzene & $\mathbf{1}$ & 55 \\
4 & Bromobenzene & $\mathbf{2}$ & 70 \\
5 & Chlorobenzene & $\mathbf{1}$ & 49 \\
6 & Chlorobenzene & $\mathbf{2}$ & 62 \\
\hline
\end{tabular}

[a] Isolated yields by column chromatography.

reaction is unclear at this stage, the active centre should be metal centre (See Table 2, entries 2-6 and 9-10 $v s$ entries 7-8). Besides, the significant role of imidazolium carboxylate ligand in the catalytic process cannot be ignored (See Table 2, entries 9-12). ${ }^{7}$

\section{Conclusions}

In conclusion, we investigated the first catalytic application of imidazolium carboxylate supported silver(I) and copper(II) assemblies for Ullmann coupling. We have also demonstrated novel structural topologies and versatile coordination properties of coordination polymers by tuning the number of flexible node at organic spacer, and employing judicious synthetic strategies. The catalysts 1 and $\mathbf{2}$ show efficient homocoupling of aryl halide reactions to generate the corresponding diaryl products in excellent yields. Their catalytic applications in Ullmann reactions have shown wide scope with different halobenzenes. Structural insights into these compounds provide an explanation for the diverse catalytic behaviour of these compounds. Future studies on the reactivity of these ligands and their coinage metal complexes toward Ullmann cross coupling (N/Oarylation) are underway in our laboratory.

\section{Supplementary Information (SI)}

CCDC 1496983-1496984 contain the supplementary crystallographic data for this paper. These data can be obtained free of charge from the Cambridge Crystallographic Data Centre via www.ccdc.cam.ac.uk/data_request/cif or from the Cambridge Crystallographic Data Centre, 12 Union Road, Cambridge CB2 1EZ, UK; fax: +44 1223336 033; or by 
email: deposit@ccdc.cam.ac.uk. Figures S1-S8 are available in Supplementary Information at www.ias.ac.in/chemsci.

\section{Acknowledgements}

We gratefully acknowledge the DST-FT (SR/FT/CS-94/2010) for financial support. CNB thanks UGC for the fellowship.

\section{References}

1. Sen S, Nair N N, Yamada T, Kitagawa H and Bharadwaj P K 2012 High Proton Conductivity by a Metal-Organic Framework Incorporating $\mathrm{Zn}_{8} \mathrm{O}$ Clusters with Aligned Imidazolium Groups Decorating the Channels J. Am. Chem. Soc. 13419432

2. Ezugwu C I, Kabir N A, Yusubov M and Verpoort F 2015 Metal-Organic Frameworks Containing NHeterocyclic Carbenes and their Precursors Coord Chem. Rev. 307188

3. (a) Lee J, Farha O K, Roberts J, Scheidt K A, Nguyen S T and Hupp J T 2009 Metal-Organic Framework Materials as Catalysts Chem. Soc. Rev. 38 1450; (b) Lee J Y, Roberts J M, Farha O K, Sarjeant A A, Scheidt K A and Hupp J T 2009 Synthesis and Gas Sorption Properties of a Metal-Azolium Framework (MAF) Material Inorg. Chem. 48 9971; (c) Nickerl G, Notzon A, Heitbaum M, Senkovska I, Glorius F and Kaskel S 2013 Selective Adsorption Properties of Cationic Metal-Organic Frameworks Based on Imidazolic Linker Cryst. Growth Des. 13 198; (d) Wang S, Yang Q, Zhang J, Zhang X, Zhao C, Jiang L and Su C-Y 2013 Two-Dimensional Charge-Separated MetalOrganic Framework for Hysteretic and Modulated Sorption Inorg. Chem. 52 4198; (e) Sen S, Neogi S, Aijaz A, Xu Q and Bharadwaj P K 2014 Construction of NonInterpenetrated Charged Metal-Organic Frameworks with Doubly Pillared Layers: Pore Modification and Selective Gas Adsorption Inorg. Chem. 53 7591; (f) Sen S, Yamada T, Kitagawa H and Bharadwaj P K 2014 3D Coordination Polymer of $\mathrm{Cd}(\mathrm{II})$ with an ImidazoliumBased Linker Showing Parallel Polycatenation Forming Channels with Aligned Imidazolium Groups Cryst. Growth Des. 141240

4. Kong G-Q, Xu X, Zou C and Wu C-D 2011 Two MetalOrganic Frameworks Based on a Double Azolium Derivative: Post-Modification and Catalytic Activity Chem. Commun. 4711005

5. Kong G-Q, Ou S, Zou C and Wu C-D 2012 Assembly and Post-Modification of a Metal-Organic Nanotube for Highly Efficient Catalysis J. Am. Chem. Soc. 13419851
6. Burgun A, Crees R S, Cole M L, Doonan C J and Sumby C J 2014 A 3-D diamondoid MOF catalyst based on in situ generated $\left[\mathrm{Cu}(\mathrm{L})_{2}\right] \mathrm{N}$-heterocyclic carbene (NHC) linkers: Hydroboration of $\mathrm{CO}_{2}$ Chem. Commun. 5011760

7. Lalonde M B, Farha O K, Scheidt K A and Hupp J T 2012 N-Heterocyclic Carbene-Like Catalysis by a Metal-Organic Framework Material ACS Catal. 21550

8. Babu C N, Suresh P, Srinivas K, Sathyanarayana A, Sampath N and Prabusankar G 2016 Catalytically Active Lead(II)-Imidazolium Coordination Assemblies with Diversified Lead(II) Coordination Geometries Dalton Trans. $\mathbf{4 5} 8164$

9. Perrin D D and Armarego W L F 1988 Purification of Laboratory Chemicals Third ed. (London: Pergamon Press)

10. (a) Wang X W, Han L, Cai T-J, Zheng Y-Q, Chen J-Z and Deng Q 2007 A Novel Chiral Doubly Folded Interpenetrating 3D Metal-Organic Framework Based on the Flexible Zwitterionic Ligand Cryst. Growth Des. 7 1027; (b) Kühl O and Palm G 2010 Imidazolium Salts from Amino Acids-A New Route to Chiral Zwitterionic Carbene Precursors? Tetrahedron Asymm. 21 393; (c) Babu C N, Sathyanarayana A, Mobin S M, Prabusankar G 2013 Structurally characterized zwitterionic chiral zinc imidazolium $[4,4]$ grid Inorg. Chem. Commun. 37222

11. Dolomanov O V, Bourhis L J, Gildea R J, Howard J A K and Puschmann H 2009 OLEX2: A complete structure solution, refinement and analysis program J. Appl. Cryst. 42339

12. Font M, Acuña-Parés F, Parella T, Serra J, Luis J M, Lloret-Fillol J, Costas M and Ribas X 2014 Direct Observation of Two-Electron $\mathrm{Ag}(\mathrm{I}) / \mathrm{Ag}$ (III) Redox Cycles in Coupling Catalysis Nat. Commun. 54373

13. Bollermann T, Prabusankar G, Gemel C, Winter M, Seidel R W and Fischer R A 2010 First Dinuclear Copper/Gallium Complexes: Supporting $\mathrm{Cu} 0$ and $\mathrm{CuI}$ Centres by Low-Valent Organogallium Ligands Chem. Eur. J. 168846

14. (a) Sambiagio C, Marsden S P, Blacker A J and McGowan P C 2014 Copper Catalysed Ullmann Type Chemistry: From Mechanistic Aspects to Modern Development Chem. Soc. Rev. 43 3525; (b) Gu Y, Chang D, Leng X, Gu Y and Shen Q 2015 Well-Defined, ShelfStable (NHC) $\mathrm{Ag}\left(\mathrm{CF}_{2} \mathrm{H}\right)$ Complexes for Difluoromethylation Organometallics 343065

15. Hassan J, Sévignon M, Gozzi C, Schulz E and Lemaire M 2002 Aryl-Aryl Bond Formation One Century after the Discovery of the Ullmann Reaction Chem. Rev. 102 1359 